\title{
Patterns of alcohol use in an elderly sample enrolled in the Family Health Strategy program in the city of Porto Alegre, Brazil
}

\author{
Padrões do uso de álcool em uma amostra de idosos \\ no município de Porto Alegre, Brasil
}

\author{
Bruno Luiz Guidolin ${ }^{1}$ \\ Irênio Gomes da Silva Filho ${ }^{1}$ \\ Eduardo Lopes Nogueira ${ }^{1}$ \\ Francisco Pascoal Ribeiro Junior ${ }^{1}$ \\ Alfredo Cataldo Neto ${ }^{1}$
}

${ }^{1}$ Pontifícia Universidade Católica do Rio Grande do Sul. Av. Ipiranga, 6681, Partenon. 90619-900 Porto Alegre RS Brasil. brunoguidolin@ yahoo.com.br

\begin{abstract}
This article aims to determine the pattern of alcohol use in the elderly and its associations with sociodemographic characteristics in an elderly sample of patients from the city of Porto Alegre, Rio Grande do Sul, Brazil. A cross-sectional study was conducted involving 557 seniors, aged 60 years or more, through application of the Mini International Neuropsychiatric Interview and a global assessment questionnaire for the elderly. The majority of the 557 senior citizens did not complete elementary school (58.3\%), were white $(65.1 \%)$, married (37.6\%), had no caregiver $(62.2 \%)$, were catholic (65.5\%) and practicing their religion (68.6\%), were retired (67.7\%), and had a personal income of up to one minimum salary (56.1\%). The study revealed 67 (12\%) elderly people with a history of alcoholism, of which $17(3.1 \%)$ had a diagnosis of current alcoholism, 50 (9\%) had a history of alcohol dependence in the past and 16 (2.9\%) had a current alcohol abuse problem. Men had a prevalence ratio of 11.6 times for a history of alcoholism in comparison to women. The results confirm that alcoholism is frequent in the population of Brazilian elder$l y$, drawing attention to some socio-demographic characteristics that can make a difference in the early diagnosis of alcoholism.

Key words Addiction, Alcohol, Elderly, Prevalence
\end{abstract}

Resumo O objetivo do artigo é determinar o padrão do uso de álcool em idosos e suas associações com as características sociodemográficas em uma amostra de pacientes do município de Porto Alegre, Rio Grande do Sul, Brasil. Este foi um estudo transversal com aplicação do Mini International Neuropsychiatric interview e Questionário de Avaliação Global do Idoso, em 557 idosos com 60 anos ou mais. Dos 557 idosos, a maioria não completou o ensino fundamental (58,3\%), era branca (65,1\%), casada (37,6\%), não apresentava cuidador $(62,2 \%)$, era católica $(65,5 \%)$ e praticante de sua religião (68,6\%), estava aposentada $(67,7 \%)$, possuia renda de um salário mínimo $(56,1 \%)$. O estudo apresentou 67 (12\%) idosos com história de alcoolismo sendo que 17 (3,1\%) mantinham esse diagnóstico, 50 (9\%) tinham história de dependência de álcool no passado e 16 (2,9\%) possuíam abuso de álcool atual. Em todas categorias os homens são maioria; o sexo masculino tem 11,6 vezes a prevalência de história de alcoolismo quando comparado com o sexo feminino. Os resultados confirmam que o alcoolismo é frequente na população de idosos brasileira, chamando a atenção para algumas características sociodemográficas que podem fazer a diferença no diagnóstico precoce do alcoolismo.

Palavras-chave Vício, Álcool, Idoso, Prevalência, Sociodemográficas 


\section{Introduction}

World population aging is rapidly occurring, especially in developing countries, leading to important social and economic challenges worldwi$\mathrm{de}^{1}$.According to the Brazilian Census, the number of elderly people in the population was $4.8 \%$ in 1991 , whereas this figure had risen to $7.5 \%$ by $2010^{2}$. It is estimated that the number of elderly people will reach 32 million by 2020 . This rise is primarily due to increased life expectancy and a decline in fertility, such that much of the current population will reach old age ${ }^{3}$.

Aging is a natural process. However, it leads to various anatomical and functional alterations in the body that will have repercussions for the state of health of the elderly. The high prevalence of chronic degenerative diseases reinforces the need for effective action in order to promote a better quality of life in old age $e^{4,5}$.

The elderly present a very complex biological phenomenon derived from an interaction between genetic and environmental factors. Changes, such as retirement, loss of friends, loneliness and social isolation can leave them vulnerable and more prone to intensification of unhealthy habits, for instance, abusive alcohol consumption ${ }^{6}$.

Alcoholism is the dependency of an individual to alcohol and is considered a disease by the World Health Organization. Constant, uncontrolled and progressive use of alcoholic drinks can seriously compromise the proper functioning of the organism, leading to disturbances of the mind, physical health, relationships with others and social and economic behaviors ${ }^{1,7}$.

Abusive alcohol consumption leads directly and indirectly to higher health system costs as the comorbidities caused by it are expensive and difficult to manage. It is equally as important to detect and resolve alcohol problems in the elderly as it is in the young; this disease can have serious repercussions in this age group. Elderly alcoholics differ from the young in various clinical aspects and, therefore, their treatment requirements are clearly distinct ${ }^{8-10}$.

Data concerning alcoholism and alcohol abuse among the elderly in Brazil is scarce. The majority of research is directed at the younger population with the aim of stimulating campaigns for the early cessation of this habit. International research in the area of elderly health care exists and reports the significance of this topic, highlighting also the importance of promoting the discontinuation of this addiction in this age group. The most efficient route to an improved prognosis for those people already suffering from alcohol related diseases, and to prevent others from developing them, is to include the elderly in public health programs for the cessation of alcohol ${ }^{11-14}$.

For the management and control of alcoholism in the elderly to be effective, it is necessary to understand the reasons why the elderly drink, the influence of family, socioeconomic conditions and the cultural environment on them, the pattern of alcohol consumption, aspects of dependency, and the interrelationships between the alcohol dependent comorbidities. A strategy for the treatment of elderly patients with alcoholic disease should be defined from this data. Frequently, elderly people do not see this habit as a disease and have difficulty in recognizing the negative effects that alcoholism can have on their health. Thus, health professionals should always be alert to the possibility of the presence of alcoholic disease in this age group ${ }^{15}$.

A lack of research in this area makes it a challenge for health care providers to investigate situations that lead to alcohol dependence syndrome in the elderly and the impact that alcoholism has on the relationships established by them. Therefore, it is necessary to examine the profile of elderly alcoholics in order to define and provide more appropriate care to alcohol dependent individuals.

Accordingly, this study aimed to determine the pattern of alcohol use and its association with sociodemographic characteristics in an elderly sample of patients enrolled in the Family Health Strategy (Estratégia de Saúde da Família) program in the city of Porto Alegre, Rio Grande do Sul, Brazil.

\section{Methods}

A cross-sectional study with prospective data collection was conducted in an elderly population (60 years or more) enrolled in the Family Health Strategy (FHS) program in Porto Alegre, Rio Grande do Sul, Brazil. This research formed part of a broader epidemiological and clinical study of the elderly attended by the FHS in the city of Porto Alegre, which was developed by the Institute of Geriatrics and Gerontology/ Pontifical Catholic University of Rio Grande do Sul (IGG/ PUCRS).

The first data collection phase was performed in the homes of the selected elderly people by trained community health workers from the participating FHS units. Data regarding lifestyle, 
sociodemographic, economic, educational and cultural aspects and clinical, nutritional and neuropsychiatric information were collected through a structured interview using a standardized questionnaire, the Global Assessment Questionnaire for the Elderly.

The Mini International Neuropsychiatric Interview 5.0.0 plus - Brazilian version (M.I.N.I. Plus) was applied in the second phase by appropriately trained doctors at the Hospital São Lucas, PUCRS. Data related to alcohol abuse and alcoholism was obtained via this instrument. Results concerning the reliability and validity of the M.I.N.I. Plus are generally satisfactory for the diagnosis of alcoholism ${ }^{16,17}$.

Both the instruments used have been validated in Brazil. They are short, easy to apply tools that have been applied in numerous scientific studies worldwide with no reports of harm to the patients who were the object of their administration. Research participants with an identified disease were referred to a relevant unit within the Health System for appropriate care.

The elderly were divided into four classes:

1. Abusive current alcohol: One or more of the following occurring within a period of 12 months: (1) recurrent substance use resulting in a failure to fulfill major obligations related to their role at work, at school or at home (2) recurrent substance use in situations in which it is physically hazardous (3) recurrent substance-related legal problems (4) continued substance use despite persistent social or interpersonal problems caused or exacerbated by the effects of the substance. Symptoms never meet the criteria for substance dependence for this class of substance.

2. Current alcohol dependence (alcoholic): Three or more of the following, occurring at any time in the same 12-month period: (1) tolerance defined by either of the following: (a) a need for low progressively larger of the substance to achieve intoxication or desired effect (b) markedly diminished effect with continued use of the same amount of substance (2) withdrawal, as manifested by any of the following: (a) characteristic withdrawal syndrome for the substance (b) the same substance (or a closely related substance) is taken to relieve or avoid withdrawal symptoms (3) the substance is often taken in larger amounts or over a longer period than was intended (4) a persistent desire or unsuccessful efforts to reduce or control substance (5) much time is spent in activities necessary to obtain the substance, the use of the substance or to recover from its effects (6) important social, occupa- tional or recreational activities are given up or reduced because of substance use (7) substance use continues despite knowledge of having a persistent or recurrent physical or psychological problem that is likely to be caused or exacerbated by the substance.

3. Previous alcohol dependency: the same criteria for alcohol dependence but a year ago on abstinence.

4. History of alcoholism: covers the dependency history of previous alcohol and current alcohol dependence.

Data was analysed using the statistics software SPSS, version 17.0. Pearson's chi-square test was employed for analysis of results between variables. A $p$ value less than or equal to 0.05 was considered to be statistically significant. Student's t-test was used to compare continuous variables. Bivariate analysis was performed using a Poisson regression model with robust variance for the statistically significant variables.

All participants were informed of the project aims and signed an informed consent form, in duplicate, for the broader project Clinical and Epidemiological Study of Seniors Served by the Family Health Strategy of the Municipality of Porto Alegre (Estudo Epidemiológico e Clínico dos Idosos Atendidos pela Estratégia de Saúde da Família do Município de Porto Alegre). One copy was retained by researchers and the other by the elderly person or their caregiver.

The overall project was assessed and approved by the Research Ethics Committee of PUCRS. Similarly, the Research Ethics Committee of the Municipal Secretariat of Health of Porto Alegre (Secretaria Municipal de Saúde de Porto Alegre) analyzed and approved the whole research project. This present research project was evaluated and approved by the scientific committee of the Institute of Geriatrics and Gerontology.

Research followed standards set out in resolution CNS 196/96, Standard Guidelines and Regulatory Research Involving Human Beings, of the National Health Council, and complied with the ethical principles contained in the Declaration of Helsinki.

\section{Results}

The number of elderly people that responded to the required questions for this study was 557 . Of these, 355 (63.7\%) were female and 202 (36.3\%) male. The most prevalent age group was 60-69 years with a total of 348 (62.5\%) elderly, followed 
by $164(29.4 \%)$ seniors aged $70-79$ years, and 45 $(8.1 \%)$ aged 80 years or more. In total, the study revealed $67(12 \%)$ elderly patients with a history of alcoholism, with 17 (3.1\%) of these having a current diagnosis of alcoholism, 50 (9\%) only being alcohol dependent in the past and 16 (2.9\%) being currently with an alcohol abuse problem.

Sociodemographic data showed that the majority of elderly individuals did not complete elementary school (58.3\%), are white $(65.1 \%)$, married $(37.6 \%)$, no longer living with their partner (52.1\%) and live with family members $(33.5 \%)$, have no caregiver $(62.2 \%)$, are catholic $(65.5 \%)$ and practicing their religion $(68.6 \%)$, are reitred $(67.7 \%)$, have a personal income of one minimum salary $(56.1 \%)$ and a household income of three minimum salaries (53.3\%). Sociodemogra- phic characteristics related to a history of alcoholism, being a current alcoholic, previous alcohol dependence and current alcohol abuse are described in Table 1.

A significant difference was seen when the variable gender was correlated with history of alcoholism, alcoholic, previous alcohol dependence and alcohol abuse $(\mathrm{p}<0.001)$ in the elderly. Men made up the majority in all the categories; history of alcoholism (28.2\%), alcoholic (8.4\%), previous alcohol dependency $(19.8 \%)$ and current alcohol abuse (6.4\%).

In the relationship between a history of alcoholism with marital status, the categories for living arrangements, having a caregiver, and if practicing religion were discovered to be significant $(p<0.05)$. It was found that the majority of

Table 1. Alcoholic, previous alcohol dependency, history of alcoholism and alcohol abuse in an elderly population resident in Porto Alegre city, Rio Grande do Sul, Brazil, according to sociodemographic characteristics, 2013 ( $\mathrm{N}=557$ elderly).

\begin{tabular}{|c|c|c|c|c|c|c|c|c|c|c|c|}
\hline \multirow[b]{2}{*}{ Variable } & \multirow[b]{2}{*}{$\begin{array}{c}\text { Population } \\
\%\end{array}$} & \multicolumn{2}{|c|}{ Alcoholic } & \multicolumn{2}{|c|}{$\begin{array}{c}\text { Previous } \\
\text { alcohol } \\
\text { dependency }\end{array}$} & \multicolumn{2}{|c|}{$\begin{array}{c}\text { History } \\
\text { of alcoholism } \\
\end{array}$} & \multicolumn{2}{|c|}{$\begin{array}{c}\text { Alcohol } \\
\text { abuse }\end{array}$} & \multicolumn{2}{|c|}{$\begin{array}{c}\text { No alcohol } \\
\text { dependency }\end{array}$} \\
\hline & & $\%$ & $\mathbf{P}^{*}$ & $\%$ & $\mathbf{P}^{*}$ & $\%$ & $\mathbf{P}^{*}$ & $\%$ & $\mathbf{P}^{*}$ & $\%$ & $\mathbf{P}^{*}$ \\
\hline Gender & & & $<0.001$ & & $<0.001$ & & $<0.001$ & & $<0.001$ & & $<0.001$ \\
\hline Male & 36.3 & 8.4 & & 19.8 & & 28.2 & & 6.4 & & 71.8 & \\
\hline Female & 63.7 & 0 & & 2.8 & & 2.8 & & 0.8 & & 97.2 & \\
\hline Age group & & & 0.149 & & 0.611 & & 0.752 & & 0.511 & & 0.752 \\
\hline 60-69 years & 62.5 & 3.7 & & 8.3 & & 12.1 & & 3.2 & & 87.9 & \\
\hline 70-79 years & 29.4 & 2.4 & & 10.4 & & 12.8 & & 0.6 & & 87.2 & \\
\hline $80+$ years & 8.1 & 0 & & 8.9 & & 8.9 & & 8.9 & & 91.1 & \\
\hline Educational level & & & 0.909 & & 0.025 & & 0.057 & & 0.912 & & 0.057 \\
\hline $\begin{array}{l}\text { Never studied or } \\
\text { functionally illiterate }\end{array}$ & 25.4 & 3.5 & & 13.5 & & 17 & & 4.3 & & 83 & \\
\hline $\begin{array}{l}\text { Elementary school } \\
\text { incomplete }\end{array}$ & 58.3 & 2.2 & & 8.3 & & 10.5 & & 1.9 & & 89.5 & \\
\hline $\begin{array}{l}\text { Elementary school } \\
\text { complete }\end{array}$ & 9.5 & 9.4 & & 3.8 & & 13.2 & & 3.8 & & 86.8 & \\
\hline High school complete & 6.8 & 0 & & 5.3 & & 5.3 & & 5.3 & & 94.7 & \\
\hline Race & & & 0.921 & & 0.071 & & 0.240 & & 0.135 & & 0.240 \\
\hline White & 65.1 & 3.1 & & 7.3 & & 10.4 & & 2 & & 89.6 & \\
\hline $\operatorname{Parda}^{* *}$ & 13.9 & 2.6 & & 9.2 & & 11.8 & & 6.6 & & 88.2 & \\
\hline Black & 18.4 & 2 & & 15.8 & & 17.8 & & 4 & & 82.2 & \\
\hline Native Indian & 2.6 & 7.1 & & 7.1 & & 14.3 & & 0 & & 85.7 & \\
\hline Marital Status & & & 0.029 & & 0.186 & & 0.006 & & 0.383 & & 0.006 \\
\hline Married & 37.6 & 5.3 & & 11.5 & & 16.8 & & 1.9 & & 83.2 & \\
\hline Separated & 16.3 & 2.2 & & 8.9 & & 11.1 & & 5.6 & & 88.9 & \\
\hline Single & 17.5 & 4.1 & & 10.3 & & 14.4 & & 3.1 & & 85.6 & \\
\hline Widowed & 28.6 & 0 & & 5.1 & & 5.1 & & 2.5 & & 94.9 & \\
\hline
\end{tabular}


Table 1. continuation

\begin{tabular}{|c|c|c|c|c|c|c|c|c|c|c|c|}
\hline \multirow[b]{2}{*}{ Variable } & \multirow[b]{2}{*}{$\begin{array}{c}\text { Population } \\
\%\end{array}$} & \multicolumn{2}{|c|}{ Alcoholic } & \multicolumn{2}{|c|}{$\begin{array}{c}\text { Previous } \\
\text { alcohol } \\
\text { dependency }\end{array}$} & \multicolumn{2}{|c|}{$\begin{array}{c}\text { History } \\
\text { of alcoholism } \\
\end{array}$} & \multicolumn{2}{|c|}{$\begin{array}{c}\text { Alcohol } \\
\text { abuse }\end{array}$} & \multicolumn{2}{|c|}{$\begin{array}{l}\text { No alcohol } \\
\text { dependency }\end{array}$} \\
\hline & & $\%$ & $\mathbf{P}^{*}$ & $\%$ & $\mathbf{P}^{*}$ & $\%$ & $\mathbf{P}^{*}$ & $\%$ & $\mathbf{P}^{*}$ & $\%$ & $\mathbf{P}^{*}$ \\
\hline $\begin{array}{l}\text { Currently living with } \\
\text { partner }\end{array}$ & & & 0.057 & & 0.037 & & 0.004 & & 0.397 & & 0.004 \\
\hline No & 52.1 & 1.7 & & 6.6 & & 8.3 & & 3.5 & & 91.7 & \\
\hline Yes & 47.9 & 4.5 & & 11.7 & & 16.2 & & 2.3 & & 83.8 & \\
\hline Currently live.... & & & 0.073 & & 0.168 & & 0.024 & & 0.633 & & 0.024 \\
\hline Alone & 19.6 & 2.8 & & 9.2 & & 11.9 & & 4.6 & & 88.1 & \\
\hline With partner only & 20.9 & 1.7 & & 11.2 & & 12.9 & & 1.7 & & 87.1 & \\
\hline With partner \& others & 25.9 & 6.2 & & 11.8 & & 18.1 & & 2.8 & & 81.9 & \\
\hline $\begin{array}{l}\text { With family but } \\
\text { without a partner }\end{array}$ & 33.5 & 1.6 & & 5.4 & & 7 & & 2.7 & & 93 & \\
\hline Has caregiver? & & & 0.831 & & 0.006 & & 0.023 & & 0.038 & & 0.023 \\
\hline No & 62.2 & 3.3 & & 6 & & 9.3 & & 1.8 & & 90.7 & \\
\hline Yes & 37.8 & 3 & & 12.9 & & 15.8 & & 5 & & 84.2 & \\
\hline Retired? & & & 0.187 & & 0.786 & & 0.642 & & 0.654 & & 0.642 \\
\hline No & 32.3 & 4.6 & & 8.6 & & 13.2 & & 3.4 & & 86.8 & \\
\hline Yes & 67.7 & 2.5 & & 9.3 & & 11.8 & & 2.7 & & 88.2 & \\
\hline Religion & & & 0.501 & & 0.429 & & 0.800 & & 0.852 & & 0.800 \\
\hline Catholic & 65.5 & 3.9 & & 8.1 & & 11.9 & & 2.8 & & 88.1 & \\
\hline Evangelist & 20 & 1.8 & & 10 & & 11.8 & & 2.7 & & 88.2 & \\
\hline Other & 11.8 & 1.5 & & 9.2 & & 10.8 & & 3.1 & & 89.2 & \\
\hline Agnostic/atheist & 2.7 & 0 & & 20 & & 20 & & 6.7 & & 80 & \\
\hline Practicing religion? & & & 0.013 & & 0.132 & & 0.008 & & 0.281 & & 0.008 \\
\hline No & 31.4 & 5.8 & & 11.1 & & 17 & & 4.1 & & 83 & \\
\hline Yes & 68.6 & 1.9 & & 7.2 & & 9.1 & & 2.4 & & 90.9 & \\
\hline Personal income ${ }^{* * *}$ & & & 0.942 & & 0.306 & & 0.388 & & 0.112 & & 0.388 \\
\hline No personal income & 8.4 & 4.5 & & 9.1 & & 13.6 & & 2.3 & & 86.4 & \\
\hline Up to $1 \mathrm{MS}$ & 56.1 & 2.7 & & 10.2 & & 12.9 & & 1.7 & & 87.1 & \\
\hline Up to $2 \mathrm{MS}$ & 28.7 & 4 & & 10.6 & & 14.6 & & 6 & & 85.4 & \\
\hline More than 2 MS & 6.8 & 2.8 & & 0 & & 2.8 & & 2.8 & & 97.2 & \\
\hline Household income $e^{* * *}$ & & & 0.433 & & 0.187 & & 0.453 & & 0.542 & & 0.453 \\
\hline Up to $1 \mathrm{MS}$ & 36.3 & 2.3 & & 10.3 & & 12.6 & & 1.7 & & 87.4 & \\
\hline Up to $3 \mathrm{MS}$ & 53.3 & 3.5 & & 10.1 & & 13.6 & & 3.5 & & 86.4 & \\
\hline More than 3 MS & 10.4 & 4 & & 2 & & 6 & & 2 & & 94 & \\
\hline Population total & $557(100)$ & 3.1 & & 9 & & 12 & & 2.9 & & 88 & \\
\hline
\end{tabular}

"Pearson's chi-square test. ${ }^{* *}$ Multi-racial Brazilian of brown skin colour and mixed-race features, considering themselves to be "Parda". ${ }^{* * *}$ Minimum salary (MS) - lowest legal employee monthly income in Brazil set by the government, $\mathrm{R} \$ 678.00$ at the time of survey.

elderly people who are married, do not actively practice their religion, have a caregiver, live with their partner and live independently from other family members presented an increased history of alcoholism.

Other significant findings were also noted, such as the relationship between alcoholism and marital status, and alcoholism with the practice of religion. The majority of elderly alcoholics are married $(p=0.029)$ and are not practicing their religion $(p=0.013)$. As with the group having previous alcohol dependence, the elderly that never studied $(p=0.025)$, that live with their partner $(\mathrm{p}=0.037)$, and have a caregiver $(\mathrm{p}$ $=0.006$ ), presented these variables as statistically significant.

Significant variables were included in a bivariate analysis using a Poisson Regression model 
with robust variance, having a history of alcoholism as the outcome. The variables included in the model were gender, marital status, currently living with a partner, lives with...., has caregiver, and practicing religion. As marital status, currently living with partner, and lives with.... were associated, we chose to include the variable with the lowest $p$ value in the model, which was living with a partner.

The prevalence ratio (PR) for history of alcohol adjusted for the variables gender, currently living with partner, have a caregiver and practicing religion are shown in Table 2.

The PR was analyzed for each of the variables and it was noted that males have 11.6 times the prevalence of a history of alcoholism when compared to females, adjusted for currently living with a partner, having a caregiver and practicing religion.

The variable, currently living with a partner, is seen as a protective factor when adjusted for gender, having a caregiver and practicing religion, as those who have a partner have 0.3 times the prevalence of a history of alcoholism, when compared to those without a partner.

The variables having a caregiver and practicing religion, when adjusted for other variables, have no statistically significant relationship with a history of alcoholism.

Table 2. Prevalence Ratio Table adjusted for history of alcoholism ( $\mathrm{N}=67$ elderly).

\begin{tabular}{|c|c|c|}
\hline Variable & $\begin{array}{l}\text { PR adjusted } \\
\text { (CI 95\%) }\end{array}$ & $\mathbf{P}$ \\
\hline Gender & & $<0.001$ \\
\hline Male & $11.6(3.0-45.2)$ & \\
\hline Female & 1 & \\
\hline Currently living with partner & & 0.016 \\
\hline Yes & $0.3(0.1-0.8)$ & \\
\hline No & 1 & \\
\hline Have caregiver & & 0.121 \\
\hline Yes & $2.2(0.8-5.7)$ & \\
\hline No & 1 & \\
\hline Practicing religion & & 0.983 \\
\hline Yes & $1.0(0.4-2.5)$ & \\
\hline No & 1 & \\
\hline
\end{tabular}

Prevalence ratios (PR) and their respective 95\% confidence intervals (CI 95\%) were calculated by Poisson Regression with robust variance.

\section{Discussion}

This study involved a community of elderly people resident in the city of Porto Alegre, capital of the state of Rio Grande do Sul, Brazil. The sample was predominantly female $(63.7 \%)$ with a mean age of $68.98 \pm 7.12$ years (range 60-103 years). The majority reported having completed less than eight years education (58.3\%), were white $(65.1 \%)$, catholic $(65.5 \%)$, with a low income (56.1\%).

The global assessment questionnaire for the elderly (QAGI) and M.I.N.I. Plus were completed by 557 participants. A diagnosis of alcoholism was seen in $3.1 \%$ of the elderly sample. Previous researches based in Brazil and including those from this particular region were analyzed. This process proved to be difficult as often the sample sizes were small and few studies exist that include residents aged over 59 years ${ }^{18,19}$.

Differing results were encountered in the national studies. The population of elderly alcoholics encountered in this present study was lower than reported in research conducted in the city of Pelotas, Rio Grande do Sul (4.3\% of the elderly proved positive for alcoholic disorders). Other research carried out in Campinas, a city in southeastern Brazil noted a rate of $2.7 \%$ of alcoholics in their elderly sample. Further national publications have demonstrated even higher prevalences of $10.6 \%$ for alcohol abuse and $15 \%$ for elderly alcoholics ${ }^{7,19-21}$.

In the first national survey of alcohol consumption carried out in Brazil involving people 60 years plus, it was estimated that $12 \%$ of respondents were individuals that drank heavily, $10.4 \%$ presented excessive alcohol consumption, and $2.9 \%$ were alcohol dependent. Research in the city of São Paulo with 1563 interviewed seniors over 60 years showed a alcoholism prevalence of $9.1 \%$, while an earlier investigation in Porto Alegre noted that $11.7 \%$ of the elderly population were alcoholic, a result that exceeds our findings ${ }^{11,15,22}$.

In a global context, the methodological, social, cultural and economic differences of the populations studied may explain the variation in prevalences encountered. A Dutch study reported $13.4 \%$ of their elderly sample to be heavy drinkers. In Finland, a survey of prevalence of patterns of alcohol consumption in the elderly $(\mathrm{n}=12,413)$ was performed with $8.2 \%$ of the sample shown to be alcoholics. The rates encountered in African publications were close to those found in this present study. In South Africa, 
an analysis of data for an elderly population of 2,144 noted that 4\% presented excessive alcohol consumption, while in Tanzania the prevalence encountered was $5.1 \%$ being alcoholic ${ }^{12,23-25}$.

The prevalence of men with a diagnosis of alcoholism encountered in our investigation was $8.4 \%$, however, not one woman was diagnosed as alcoholic. The prevalence for alcohol dependence in the past was $19.8 \%$ in men and $2.8 \%$ in women. These results suggest that alcohol abuse can be hidden from many clinicians; patients may deny the current use of alcohol but confirm its use in the past, even when guaranteed confidentiality of information. Additionally, excessive alcohol consumption may be more common in elderly women than is generally assumed. This gender difference may somehow be attributed to socio-cultural norms that prevent women from admitting their abuse $e^{22,26-29}$.

An American study in which 4236 elderly people over 65 years were interviewed found that $13 \%$ of men and $8 \%$ of women in its population reported excessive alcohol consumption. This research shows how male and female populations may be very close in their involvement with alcohol $^{29}$.

In India, an investigation of patterns of alcohol consumption involving only men $(n=228)$ found that $5.3 \%$ had a past history of alcoholism and 14\% were diagnosed as alcoholics. Such findings corroborate the hypothesis of denial of current alcohol use, as indicated in the data from this present study set in Porto Alegre ${ }^{30}$.

The controlled analysis revealed that the male gender was the factor most strongly associated with a history of alcoholism (PR: 11.6 / 3.0 - 45.2, $\mathrm{p}<0.001)$. There are several studies in the scientific literature also demonstrating that this population subgroup has a greater risk of developing alcoholism $^{20,22,27,31,32}$.

Another relevant association with a history of alcoholism was observed in the elderly who live with their partners (PR: $0.3(0.1-0.8), \mathrm{p}=$ $0.016)$. Having a companion is a protective factor in our research. Some articles disagree with this association, while there are others studies reporting increased rates of alcoholism in populations not living with a partner. It was observed in a community research (6717 individuals between 50-64 years and $4236 \geq 65$ years) that to be separated, divorced or widowed was associated with excess alcohol consumption in men ${ }^{13,33-35}$.
The practice of religion by the elderly presented no statistically significant relationship with a history of alcoholism, when adjusted for other variables. Nevertheless, other research has shown the importance of being religious in alcohol abstinence. A Canadian study that investigated the prevalence of alcoholism linked to religion in Korean immigrants demonstrated that a greater practice of religion correlated with a lower likelihood of heavy drinking in both men and women). Other research noted a protective relationship between practicing religion and developing excessive alcohol consumption). A Brazilian study found a lower incidence of alcoholism in people that frequented their churches (catholics $8.7 \%$, evangelists $3.1 \%$, spiritualists $10.2 \%$ ) when compared to those without religious beliefs $(18.3 \%)^{33,36,37}$.

The present study has methodological limitations, among which we can mention: it is a crosssectional study and, therefore, it is not possible to precisely define what is cause and what is effect. Longitudinal studies would be necessary to confirm this, however, even with a guarantee of confidentiality, some patients do not reveal their true pattern of alcohol consumption. Regardless of these limitations, the findings of this research corroborate the results found in the literature.

In conclusion, this research is based on a representative sample of community residents aged 60 years or more in Brazil. The results demonstrated that alcoholism is frequent in a population of elderly residents in a developing country, such as Brazil.

The abusive use of alcohol can cause numerous health problems in the elderly. These substance-related problems are becoming a serious global public health issue. Thus, further research on this topic is necessary in order to have a better understanding of sociocultural variations of alcohol use in the elderly population.

Various actions can be taken to combat this silent epidemic. Brief interventions and structured treatment strategies are indicated and the regular evaluation of alcohol use by short assessment questionnaires can be used during medical encounters. Public awareness, the planning of health services in order to provide effective interventions, prevention campaigns in the community and changes in policy based on evidence that takes into account the characteristics of the elderly in the community, can all make a difference in the early diagnosis and treatment of alcoholism in this population. 


\section{Collaborations}

BL Guidolin, IG Silva Filho and A Cataldo Neto participated conception, design, analysis and interpretation the results, writing and critical review article. EL Nogueira and FP Ribeiro Júnior participated analysis and interpretation of results and drafting of the manuscript.

\section{References}

1. World Health Organization (WHO). What are the public health implications of global ageing? Geneva: WHO; 2011.

2. Instituto Brasileiro de Geografia e Estatística (IBGE). Resultados da amostra do Censo 2010. Rio de Janeiro: IBGE; 2012.

3. Instituto Brasileiro de Geografia e Estatística(IBGE). Projeção da população brasileira, revisão 2008 - 19802050. Estudos e pesquisas.[periódico na Internet]. 2008 [acessado 2015 maio 5]. Disponível em: http:// www.ibge.gov.br/home/estatistica/populacao/projecao_da_populacao/2008/projecao.pdf

4. Iserr BPM, Claro RM, Moura EC, Malta DC, Neto OLM. Fatores de risco e proteção para doenças crônicas não transmissíveis obtidos por inquéritos telefones - VIGITEL Brasil - 2009. Rev bras epidemiol 2011; 14(1):90-102.

5. Jacob Filho W. Epidemiologia do Envelhecimento. In: Jacob Filho W, Kikuchi EL. Geriatria e Gerontologia Básicas. São Paulo: Elsevier; 2012. p. 7-9.

6. Ferreira NF, Bispo Júnior JP, Sales ZN, Casotti CA, Braga Júnior CRB. Prevalência e fatores associados ao consumo abusivo e à dependência de álcool. Cien Saude Colet 2013; 18(11):3409-3418.

7. Laranjeira R, Pinsky I, Sanches M, Zaleski M, Caetano R. Alcohol use patterns among Brazilian adults. Rev Bras Psiquiatr 2010; 32(3):231-241.

8. Kuerbis A, Sacco PA. Review of Existing Treatments for Substance Abuse Among the Elderly and Recommendations for Future Directions. Subst Abuse 2013; 7:13-37.

9. Hoeck S, Van Hal G. Unhealthy drinking in the Belgian elderly population: prevalence and associated characteristics. Eur J Public Health 2013; 23(6):1069-1075.

10. Gross AL, Rebok GW, Ford DE, Chu AY, Gallo JJ, Liang KY, Meoni LA, Shihab HM, Wang NY, Klag MJ. Alcohol cconsumption and ddomain-sspecific ccognitive ffunction in oolder aadults: longitudinal ddata from from the johns hopkins precursors study. Journal of Gerontology: Psychological Sciences 2010; 66B(1):39-47.

11. Hirata ES, Nakano EY, Junior JA, Litvoc J, Bottino CM. Prevalence and correlates of alcoholism in community-dwelling elderly living in São Paulo, Brazil. Int J Geriatr Psychiatry 2009; 24(10):1045-1053.

12. Comijs HC, Aartsen MJ, Visser M, Deeg DJ. Alcohol consumption among persons aged 55+ in The Netherlands. Tijdschr Gerontol Geriatric 2012; 43(3):115-126.

13. Immonen S, Valvanne J, Pitkala KH. Prevalence of at-risk drinking among older adults and associated sociodemographic and health-related factors. J Nutr Health Aging 2011; 15(9):789-794.

14. Lin JC, Karno MP, Grella CE, Warda U, Liao DH, Hu P, Moore AA. Alcohol, tobacco, and nonmedical drug use disorders in U.S. Adults aged 65 years and older: data from the 2001-2002 National Epidemiologic Survey of Alcohol and Related Conditions. Am J Geriatr Psychiatry 2011; 19(3):292-299. 
15. Senger AEV, Ely LS, Gandolfi T, Schneider RH, Gomes I, De Carli GA. Alcoholism and smoking in the elderly: relation to dietary intake and socioeconomic aspects. Rev Brasileira de Geriatria e Gerontologia 2011; 14(4):713-719.

16. Amorim P. Mini International Neuropsychiatric Interview (MINI): validation of a short structured diagnostic psychiatric interview. Rev Bras Psiquiatr 2000; 22(3):106-115.

17. Sheehan DV, Lecrubier Y, Seehan KH, Amorim P, Janavs J, Weiller E, Hergueta T, Baker R, Dunbar GC. The Mini-International Neuropsychiatric Interview (M.I.N.I.): The development and validation of a structured diagnostic psychiatric interview for DSM-IV and ICD-10. J Clin Psychiatry 1998; 59(20):22-33.

18. Silveira CM, Siu ER, Anthony JC, Saito LP, de Andrade AG, Kutschenko A, Viana MC, Wang YP, Martins SS, Andrade LH. Drinking patterns and alcohol use disorders in São Paulo, Brazil: the role of neighborhood social deprivation and socioeconomic status. PLoS One 2014; 9(10):e108355.

19. Silveira CM, Viana MC, Siu ER, de Andrade AG, Anthony JC, Andrade LH. Sociodemographic correlates of transitions from alcohol use to disorders and remission in the São Paulo megacity mental health survey, Brazil. Alcohol Alcohol 2011; 46(3):324-332.

20. Fillenbaum GG, Blay SL, Andreoli SB, Gastal FL. Correlates of and relationship among lifetime alcohol abuse and alcohol dependence in older community residents in Brazil. Int Psychiatry 2009; 6(2):40-44.

21. Blay SL, Fillenbaum GG, Andreoli SB, Gastal FL. Correlates of lifetime alcohol misuse among older community residents in Brazil. Int Psychogeriatr 2009; 21(2):384391.

22. Nadkarni A, Acosta D, Rodriguez G, Prince M, Ferri CP. The psychological impact of heavy drinking among the elderly on their co-residents: the 10/66 group population based survey in the Dominican Republic. Drug Alcohol Depend 2011; 114(1):82-86

23. Wu LT, Blazer DG. Substance use disorders and psychiatric comorbidity in mid and later life: a review. Int J Epidemiol 2014; 43(2):304-317.

24. Peltzer K, Phaswana-Mafuya N. Problem drinking and associated factors in older adults in South Africa. Afr J Psychiatry 2013; 16(2):104-109.

25. Negin J, Cumming R, de Ramirez SS, Abimbola S, Sachs SE. Risk factors for non-comunicable diseases among older adults in rural Africa. Trop Med Int Health 2011; 16(5):640-646.

26. Tait RJ, French DJ, Burns R, Anstey KJ. Alcohol use and depression from middle age to the oldest old: gender is more important than age. Int Psychogeriatr 2012; 24(8):1275-1283.
27. Barnes AJ, Moore AA, Xu H, Ang A, Tallen L, Mirkin M, Ettner SL. Prevalence and correlates of at-risk drinking among older adults: The project SHARE study. J Gen Intern Med 2010; 25(8):840-846.

28. Nielsen B, Anette Søgaard Nielsen AS, Lolk A, Andersen K. Elderly alcoholics in outpatient treatment. Danish Medical Bulletin 2010; 57(11):A4209.

29. Keyes KM, Martins SS, Blanco C, Hasin DS. Telescoping and gender differences in alcohol dependence: new evidence from two national surveys. Am J Psychiatry 2010; 167(8):969-976.

30. Ghosh S, Mukherjee S, Samanta A. Patterns of alcohol consumption among male adults at a slum in Kolkata, India. J Health Popul Nutr 2012; 30(1):74.

31. Wang YP, Andrade LH. Epidemiology of Alcohol and Drug Use in the Elderly. Current Opinion in Psychiatry 2013; 26(4):343-348.

32. Caputo F, Vignoli T, Leggio L, Addolorato G, Zoli G, Bernardi M. Alcohol use disorders in the elderly: a brief overview from epidemiology to treatment options. Experimental Gerontology 2012; 47(6):411-416.

33. Booth BM, Borders TF, Curran GM, Mattox R. Religiousness among at-risk drinkers: is it prospectively associated with the development or maintenance of an alcohol-use disorder? J Stud Alcohol Drugs 2010; 71(1):136.

34. Rognmo K, Fartein A, Torvik FA, Mariann Idstad M, Tambs K. More mental health problems after divorce in couples with high pre-divorce alcohol consumption than in other divorced couples: results from the HUNT-study. BMC Public Health 2013; 13:852.

35. Blazer DG, Wu LT. The Epidemiology of At-Risk and Binge Drinking Among Middle-Aged and Elderly Community Adults: National Survey on Drug Use and Health. Am J Psychiatry 2009; 166(10):1162-1169.

36. Wooksoo K. How Gender and Religion Influence Alcohol Use in Elderly Korean Immigrants. Journal of Applied Gerontology 2012; 31(2):173-192.

37. Sanchez ZM, Opaleye EM, Chaves TV, Noto AR, Nappo SA. God Forbids or Mom Disapproves? Religious Beliefs That Prevent Drug Use Among Youth. Journal of Adolescent Research 2011; 26(5):591-616.

Artigo apresentado em 08/06/2015

Aprovado em 22/08/2015

Versão final apresentada em 24/08/2015 